UDC 338.33:678.065

JEL Classification M 21

Parshyna O.A. ${ }^{a}$, Chernysheva O.M. ${ }^{b}$, Yashkina N.V. ${ }^{b}$

\title{
SCIENTIFIC AND METHODOLOGICAL PROVIDING OF THE FORMING PROCESS OF THE CHEMICAL INDUSTRY ENTERPRISES STRATEGY
}

\author{
${ }^{a}$ Dniepropetrovsk State University of Internal Affairs, Dnipro, Ukraine \\ b Ukrainian State University of Chemical Technology, Dnipro, Ukraine
}

\begin{abstract}
The article is dedicated to the reasoning of the components of scientific and methodological providing the process of the chemical industry enterprises strategy formation. It has been noted that the integration processes of domestic enterprises of the chemical industry predetermine the necessity of the elaboration of new approaches to the strategy formation in conditions of the increasing of competition on the domestic and foreign markets. Through analysis of scientific papers the feasibility of individual approach to substantiating the methodological recommendations for the content of stages of the enterprise strategy formation for a single industry sector has been proved. These stages are based on the improving the competitiveness of products. It has been noted that the providing of sustainable development should become the object of activity of the chemical industry enterprises. The system of the formation of the tire enterprises strategy has been constructed. The management subsystem within it is based on the elements of the economic mechanism meanwhile the process - on the stages of the regulation of the level of competitiveness of tires standard size. The scientific and methodological providing the process of the tire enterprises strategy formation has been offered. This providing covers a set of economic methods, means, levers and tools for every stage of regulation of the level of competitiveness of separate standard size of tires in the strategic management zones as well as a determination of the geographic vector of growth, competitive advantages, synergism and strategic flexibility of the strategic management zones portfolio for the assistance to enterprise sustainable development. The specific indexes of this providing are: integral index of estimation and potentially possible level of competitiveness of a model of separate standard size of tires as well as the reserve of the enterprise product competitiveness. Minimum level of competitiveness for the providing the consumer attractiveness of the product and minimum level of management outcome of competitiveness of the enterprise product have been offered as standards of integral index of competitiveness of a model of separate standard size of tires.
\end{abstract}

Keywords: enterprise strategy, process of strategy formation, product competitiveness, chemical industry, tire production.

DOI: $10.32434 / 2415-3974-2019-9-1-117-124$

\section{Introduction and statement of the problem}

The integration processes of domestic enterprises of the chemical industry in the world economic space include the transformation of the composition and structure of the markets as well as the requirements for quality and technology of production and the change of raw material base of production. These processes predetermine the necessity of the elaboration of new approaches to the strategy formation in conditions of the increasing of competition on the domestic and foreign markets.

Whereas the production of chemical industry

(C) Parshyna O.A., Chernysheva O.M., Yashkina N.V., 2019 enterprises is based on the raw material potential of countries and regions of the location and provides the material and raw material base of many branches of the national economy as well as products are widely consumed, enterprises are forced to look for ways to increase the validity of strategic decisions for ensuring sustainable development based on meeting the needs of consumers.

The availability of scientific and methodological support for the process of a strategy formation taking into account the industry specific might improve the quality of strategic management and substantiate the elements of the strategy of enterprises of the 
chemical industry.

\section{Analysis and investigation of publications}

A large number of scientific works is devoted to the investigation of problems of the strategic development of domestic chemical industry enterprises. P.H. Pererva points out the expediency of taking raw material, energy and environmental factors into account when formation a development strategy [7, pp.115-117]. V.V. Oleshko proves the necessity of considering the concept of sustainable development for the substantiating the mission and objectives of the chemical industry enterprises [3, P.61-63]. The multi-vector sector dynamics has been proved in works [1, P.27; 14, P.249]. It directs for the expediency of application of individual approach to the elaboration of development strategy for enterprises of every sector of chemical industry. Herewith H.Z. Shevtsova points out the need to leave the traditional model of competitiveness and use the neoindustrial model by the separate segments [14, P.252] and T.V. Kovenia - the formation of longtime strategy of development, basic competitive advantages and strategic marks of industry development according to the context of neoindustrialization [1, P.46].

The works of I.I. Pavlenko [4-5] and O.V. Khadzhynova [9] are devoted to the problems of estimation and increasing of competitiveness of chemical industry enterprises. The industry competitiveness has been investigated in work of N.V. Shvets and H.Z. Shevtsova [13]. The methodical approaches to the product competitiveness estimation for every sector of the chemical industry have been substantiated in the work [4, P.67].

The problem of formation the strategy is really actually in the tire production which has decreasing competitiveness of the domestic products [12, P.8]. The system approach to the formation of competitive advantages and increasing competitiveness of tires has been offered by authors [6, P.202-207; 10, P.238-244].

In spite of the existence of the scientific developments for the formation of the strategy of chemical industry enterprises, there are no of scientific and methodological recommendations for the formation of a strategy of enterprises of the separate sectors including the sectors with low level of products competitiveness. In addition, the researches of the products competitiveness in separate sectors of the industry, particularly, in the tire production, have no the scientific and methodological recommendations for a content of the stages of the strategy formation process based on the increasing the level of products competitiveness.

The purpose of the article

The purpose of the article is to substantiate the content of components of the scientific and methodological providing of the process of formation the tire enterprises strategy based on the regulation of the level of products competitiveness.

\section{Presentation the main material}

I.A. Fedorenko proves the expediency of system approach to the increasing of competitiveness [8, P.8-10]. N.S. Krasnokutska determines the elements of mechanism of enterprise value-oriented management; main of them is the management process [2, P.23-29]. The application of system approach to the increasing of product competitiveness reveals the elements of the system of formation the tire enterprises strategy (SFTES). These elements have been determined with taking into account the conditions of production, sales and consumption of products as well as the impact factors on products competitiveness. These elements are: object, management and managed subsystems, internal and external impact factors on the competitiveness of enterprise products (CEP), management actions.

In work [11] it has been noted that competitiveness of the diversified enterprises should be estimated at the levels of separate strategic business areas and the enterprise as a whole. The measures to improve the competitiveness of the enterprise predict, particularly, two levels of objects and strategies and should be formed according to these levels of marks.

The increasing of influence of ecologic factors in the production and consumption of the products of the chemicals industry enterprises directs to the necessity of providing the sustainable development as the main object of the activity of the enterprises. In the context of the formation of a strategy of the chemical industry enterprises the author [3, P.62] proposes to understand as a sustainable development "the radial optimization of the use of resources during the economic activity and consumption, production of such development priorities that organically combine the economic and social efficiency of the economic activity with environmental aspects", whereas this definition accurately reflects the ecological and economic content of sustainability. In our opinion, the concept of sustainable development of the tire enterprises (TE) should be taken into account in these ways: at the product level - providing the environmental friendliness of products, introduction the new products with higher level of competitiveness into production or increasing the level of competitiveness for the operating on the market products; at the enterprise level - providing the sustainable development of the TE through the keeping or acceleration of growth rates of financial and economic indexes of activity.

In work [12, P.3] it has been proved that the individual approach to every group of tires should be applied, the impact factors on the level of 
competitiveness of the products of TE (CPTE) should be taken into account, the strategic positioning of new and modernized products in dependence on the level of their competitiveness should be carried out and the sustainable development of enterprises should be provided to increase of the competitiveness of tires.

Therefore, the elements of portfolio strategy of the TE are formed simultaneously within the process of the regulation of level of the competitiveness of separate standard size of tires. Moreover, these elements should be applied to every group of tires as for a separate strategic management zone (SMZ).

For last 20 years the requirements to provide the sustainable development of TE have shifted from the mass production of narrow and stable assortment in the groups of tires to the serial production of wide and dynamic assortment of competitiveness products during the process of transformation of production of tires according to the consumers needs. Therefore, the determination of optimal volumes of production should be considered as a one of the components of the process of regulation of the level of products competitiveness in the conditions of the aggravation of competition on the domestic and foreign markets.

The elements of economic mechanism economic methods, means, levers and tools for carrying out the relating influence on the level of products competitiveness by an enterprise as a subject of strategic management through its responsible subdivisions - are proposed in this article as a management subsystem in the SFTES as well as the stages of regulation process of the level of competitiveness of standard size of tires for determination the content of components of the TE portfolio strategy - are proposed as a process in the SFTES.

In our opinion, the scientific and methodological providing the process of formation of the tire enterprises strategy (SMPPFTES) covers a set of economic methods, means, levers and tools for every stage of regulation of the level of competitiveness of separate standard size of tires in the SMZ as well as a determination of the geographic vector of growth, competitive advantages, synergism and strategic flexibility of the portfolio of SMZ for the assistance to enterprise sustainable development. The indexes and normals for carrying out the regulation of the level of competitiveness of standard size of tires are offered as tools of the SMPPFTES.

The formation of a strategy of the TE based on the regulation of level of products competitiveness (Figure) is proceeded through taking into account the managed by enterprise in the conditions of production, sales and consumption internal and external factors of CPTE as well as carrying out the regulative influence on the level of competitiveness of separate standard size of tires in every SMZ. The regulative influence on the level of competitiveness of new and operating on the market products according to the SMZ is a result of managerial actions. In particular, the management decisions to increase of CPTE at the strategic, tactical and operative levels are made and creates conditions for sustainable development of the TE.

The proposed SFTES contributes to the solution of following methodological tasks for increasing of CEP:

a) to consider the product range of the enterprise by groups of tires as a portfolio of SMZ and formulate management measures specifically for every group of tires. These SMZ should be balanced with each other with the maximum economic result;

b) to determine the components of the SMPPFTES by means of the elements of economic mechanism - methods, means, levers and tools;

c) to determine the content of the MPPFTES according to the results of analysis of the TE functioning, consumption and foreign economic activity on the tire market and to add the results of integral estimation of the SFTES for determination of the indexes of the SMPPFTES; to determine the normals of the SMPPFTES based on the normative and limits of indexes of the integral estimation of SFTES and analysis of the TE functioning;

d) to combine the process of regulation of the level of competitiveness of standard size of tires in SMZ with formation of components of the TE strategy which permit to substantiate the directions of the enterprise development.

According to the offered the SFTES, the content of strategy components, as a mean of achievement of the enterprise object, is revealed as well as the efficiency of management of the competitiveness of products and the portfolio of the TE SMZ is increased.

The components of SFTES are determined including both the results of the analysis of the TE functioning and the estimation the level of competitiveness of the separate standard size of tires by the integral index (Table). Specific for tire production methods are: comparison of price and cost of tires with average price and cost, analysis of structure of tire cost, statistic analysis of the tires cost (assist to determine the regularities in changing of production costs), taking into account the prices for rubber and main tire products in the foreign economic activity during the analysis of price and cost of tire. The unique means in the SMPPFTES: combination of producer's capabilities, customer's requirements and sales conditions in the formation of the indexes of the CPTE; substantiation of the components of strategy when making the decisions 


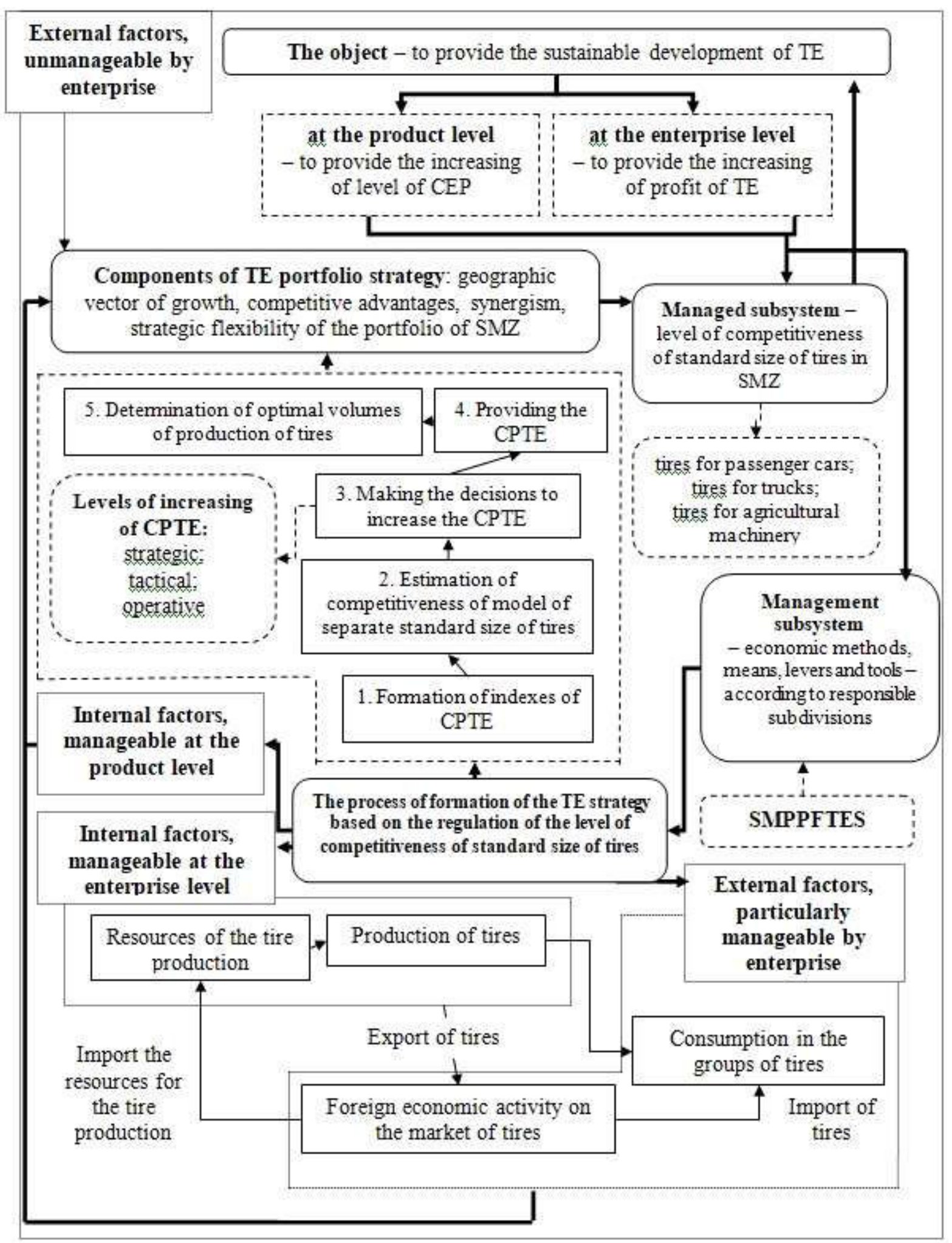

The system of formation of the tire enterprises strategy based on the regulation of level of products competitiveness (SFTES)

Note: constructed by authors 


\section{Scientific and methodological providing the process of formation of the tire enterprises strategy based on the regulation of level of products competitiveness}

\begin{tabular}{|c|c|c|c|c|}
\hline \multirow{2}{*}{$\begin{array}{c}\text { Stage of process of } \\
\text { the formation of the } \\
\text { TE strategy }\end{array}$} & \multicolumn{4}{|c|}{ Component of SMPPFTES } \\
\hline & method & mean & lever & tool (index, normal) \\
\hline $\begin{array}{l}\text { Formation of } \\
\text { indexes of CPTE }\end{array}$ & $\begin{array}{c}\text { expert } \\
\text { assessment }\end{array}$ & $\begin{array}{c}\text { combination of producer's } \\
\text { capabilities, customer's } \\
\text { requirements and sales } \\
\text { conditions }\end{array}$ & \begin{tabular}{|c|} 
constructional \\
parameters, composition \\
of materials, productivity \\
of equipment, parameters \\
of security, \\
comfortableness, \\
environmental \\
friendliness, economical \\
of tires, price, cost \\
\end{tabular} & $\begin{array}{c}\text { individual competitiveness } \\
\text { indexes for production and } \\
\text { consumption conditions; normals } \\
\text { of mileage, resource, physical } \\
\text { and mechanical characteristics of } \\
\text { rubber, tire technical } \\
\text { specifications }\end{array}$ \\
\hline $\begin{array}{l}\text { Estimation of } \\
\text { competitiveness of } \\
\text { model of separate } \\
\text { standard size of } \\
\text { tires } \\
\end{array}$ & $\begin{array}{l}\text { ballroom } \\
\text { assessment, } \\
\text { expert } \\
\text { assessment }\end{array}$ & calculation, expert & $\begin{array}{c}\text { coefficients of indexes } \\
\text { weight }\end{array}$ & $\begin{array}{l}\text { indexes: } \mathrm{C}_{\mathrm{int}}^{\mathrm{m}}, \mathrm{R}_{\mathrm{CEP}}^{\mathrm{m}} \\
\text { normal: } \mathrm{C}_{\mathrm{int}}^{\mathrm{n}}\end{array}$ \\
\hline $\begin{array}{l}\text { Making the } \\
\text { decisions to } \\
\text { increase the CPTE }\end{array}$ & $\begin{array}{l}\text { optimization, } \\
\text { comparison }\end{array}$ & \begin{tabular}{|} 
providing the optimality, \\
profit growth rates, \\
formation of the \\
components of geographic \\
vector of growth and \\
competitive advantages, \\
exploitation of synergistic \\
effect, providing the \\
strategic flexibility of the \\
portfolio of SMZ \\
\end{tabular} & $\begin{array}{c}\text { volume of production, } \\
\text { price, cost, components } \\
\text { of strategy (coordinates } \\
\text { of the geographic vector } \\
\text { of growth, competitive } \\
\text { advantages, synergism, } \\
\text { strategic flexibility of } \\
\text { the portfolio of SMZ) }\end{array}$ & 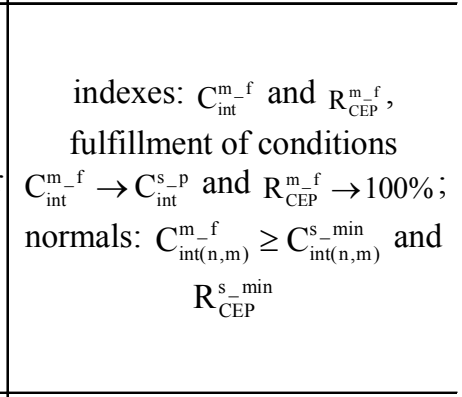 \\
\hline $\begin{array}{l}\text { Providing the } \\
\text { CPTE }\end{array}$ & $\begin{array}{c}\text { financial } \\
\text { analysis, factor } \\
\text { analysis }\end{array}$ & $\begin{array}{c}\text { comparison with normative } \\
\text { and limits of economic and } \\
\text { financial indexes, } \\
\text { comparison of dynamics, } \\
\text { application of quantitative } \\
\text { and structure and price } \\
\text { factors } \\
\end{array}$ & \begin{tabular}{|} 
condition of fixed \\
assets, structure and \\
volume of working \\
capital, level of \\
technology, quality of \\
resources
\end{tabular} & $\begin{array}{c}\text { absolute and relative financial } \\
\text { and economic indexes; } \\
\text { normative level of financial } \\
\text { indexes }\end{array}$ \\
\hline $\begin{array}{l}\text { Determination of } \\
\text { optimal volumes of } \\
\text { production of tires }\end{array}$ & \begin{tabular}{|c|} 
statistical \\
analysis, \\
analysis of the \\
structure of \\
production, \\
economic and \\
mathematical \\
modelling \\
\end{tabular} & $\begin{array}{l}\text { taking into account the } \\
\text { customers requirements } \\
\text { and enterprise resource } \\
\text { capabilities }\end{array}$ & $\begin{array}{l}\text { materials and energy } \\
\text { costs, labour costs, } \\
\text { break-even of } \\
\text { production, } \\
\text { requirements of the } \\
\text { market }\end{array}$ & $\begin{array}{c}\text { indexes: volume of production of } \\
\text { model of tires, profit of TE, } \\
\text { scarcity of resources; } \\
\text { normals: minimum and } \\
\text { maximum volumes of } \\
\text { production, normals of working } \\
\text { capital, wages fund, maximum } \\
\text { profit } \\
\end{array}$ \\
\hline
\end{tabular}

Note: offered by authors

to increase the CPTE.

Specific levers in the SMPPFTES are: constructional parameters, composition of materials, productivity of equipment, parameters of security, comfortableness, environmental friendliness, economical, price and cost of tires - in the formation of the indexes of the CPTE; condition of fixed assets, structure and volume of working capital, level of technology, quality of resources - when providing the CPTE; volume of production, price, cost and components of strategy - during making the decisions to increase the CPTE; materials and energy costs, labour costs, break-even of production, requirements of the market - in the determination of optimal volumes of production of tires.

The indexes in the stage of making the decisions to increase the CPTE are: actual levels of integral index of competitiveness of the model of the separate standard size of tires $\left(\mathrm{C}_{\mathrm{int}}^{\mathrm{m} f \mathrm{f}}\right)$ and reserve of competitiveness $\left(\mathrm{R}_{\mathrm{CEP}}^{\mathrm{m}} \mathrm{f}\right)$, offered in work [12, pp.79]. Estimation of the decisions takes place through the comparison of $\mathrm{C}_{\mathrm{int}}^{\mathrm{m}} \mathrm{f}_{\mathrm{f}}^{\mathrm{f}}$ with potentially possible level of competitiveness of the separate standard size of tires $\mathrm{C}_{\mathrm{int}}^{\mathrm{s} \mathrm{p}}$ and approximation $\mathrm{R}_{\mathrm{CEP}}^{\mathrm{m}-\mathrm{f}}$ to $100 \%$. As a 
normal of the integral index of competitiveness of the model of standard size of tires for new or modernized products is minimum level of competitiveness to provide the consumer attractiveness of new or modernized products $\left(\mathrm{C}_{\mathrm{int}(\mathrm{n}, \mathrm{m}) \mathrm{m})}^{\mathrm{sin}}\right)$ and minimum level of management outcome of competitiveness enterprise product $\left(\mathrm{R}_{\mathrm{CEP}}^{\mathrm{s} \text { min }}\right)$ [12, P.11]. In addition, limit value of the TE profit is its maximum in the current conditions of production and consumption of tires determined by means of the optimization methods.

Making the decisions to increase the CPTE at the various levels (strategic, tactical and operative) is based on the mark of integral index of the CPTE and application the reserve to increase the CEP as well as economic effect of tire production. Management decisions to increase the CPTE should be classified according to their influence on the qualitative index in conditions of production: constructions (operative level), decisions for structural materials and rubber (tactical level) and decisions for production technology (strategic level) [15, pp.189-190].

The components of integral index of competitiveness of a model of the separate standard size of tires (weight of influence of the producer's capabilities and customer's requirements on the qualitative and costly characteristics of product on the markets of the separate group of tires, indexes of quality of tires in the consumption conditions, relative index of tire cost in the production conditions) should be applied as a methodical substratum for the definition of coordinates of the geographic vector of growth (market geography, require, technology and resources).

The classification of competitive advantages in the tire production is formed according to the composition of the individual indexes of tires quality in the conditions of consumption and production as well as structure of cost for the separate group of tires. Therefore, this classification predicts the product differentiation by construction, material and technological components as well as low costs by articles of cost of the production of tires [16, pp.146152].

Synergistic effects in the tires production and consumption should be determined based on the share of material costs in the cost of production and coefficients of pair correlation between groups of tires in the production, consumption and export of tires.

The portfolio of SMZ should be combined due to the optimal volumes of production of tires determined by means of the maximization of gross profit under existing restrictions on the cost of the TE resources based on the problem of linear programming. The impact factors on the volumes of production of the tires and shortfall risks of planned profit and rubbers as a main resource should be taken into account in the optimization model.

\section{Conclusions}

It has been proved that a strategy of the chemical industry enterprises should be formed individually for every sector of industry. The scientific and methodological providing the process of formation of the tire enterprises strategy has been substantiated by means the stages of the regulation of the level and components of economic mechanism to increase the competitiveness of tires. This providing is based on the integral estimation of the level competition of every model of tires and predicts the determination of content of the components of portfolio strategy to grow gross profit by improving the competitiveness of products.

\section{REFERENCES}

1. Kovenia T.V. System assessment of the main changes in the Ukrainian chemical industry in 2017 and previous years // Khimichna promyslovist Ukrainy - Chemical Industry of Ukraine. - 2017. - No. 3. - P.19-46.

2. Krasnokutska N.S. Concept of value-oriented management of the enterprise potential] // Aktualni problemy ekonomiky - Actual Problems of Economic. - 2012. - No. 8. P.23-29.

3. Oleshko V.V. Mission and goals of the sustainable development of the chemical industry enterprises // Ahrosvit Agro World. - 2015. - No. 9. - P.60-64.

4. Pavlenko I.I. Methodological approaches to the estimation of competitivness of the chemical industry enterprises // Derzhava ta rehiony - State and Regions. -2016 . - No. 1 (88). - P.65-68.

5. Pavlenko I.I. Estimation of the potential of increasing of the competitiveness of the chemical industry enterprises // Teoretychni ta praktychni aspekty ekonomiky intelektualnoi vlasnosti - Theoretical and Practical Aspects of the Economy of Intellectual Property. - 2015. - No. 2 (12). - Vol.3. - P.8-13.

6. Pavlenko I.I. Formation of the competitive advantages in the tire production // Ekonomichnyi prostir - Economic Space. - 2016. - No. 106. - P.200-208.

7. Pererva P.H. Formation of the strategy of development of the chemical industry enterprises // Visnyk NTU "KhPI" Bulletin of NTU "KhPI". - 2013. - No. 21. - P.112-119.

8. Fedorenko, I.A. Development of heat and energy regional markets in the conditions of competitive environment // Investytsii: praktyka ta dosvid - Investments: Practice and Experience. - 2013. - No. 11. - P.8-10.

9. Khadzhinova Ye.V. Integration associations as a factor to increase the competitiveness of enterprises of the chemical industry // Teoretychni ta praktychni aspekty ekonomiky intelektualnoi vlasnosti - Theoretical and Practical Aspects of the Economy of Intellectual Property. - 2015. - No. 2 (12). Vol.2. - 185-193. 
10. Khadzhinova Ye.V. System approach to the increasing of the competitiveness of enterprises of the tire production // Ekonomichnyi prostir - Economic Space. - 2016. - No. 108, P.236-245.

11. Chernysheva O.M. Methodology of management of the competitiveness of the diversified enterprise // Proceeding of Chemistry and Modern Technologies: V Mizhnarodna naukovotelhnichna konferentsia "Khimia ta suchasni tekhnolohii" - The Fifth International Scientific and Technical Conference "Chemistry and Modern Technologies". - 2011. - Vol.2. - P.79.

12. Chernysheva O.M. Estimation of the tire enterprises production competitiveness // Extended abstract of candidate's thesis. - Kharkiv: NTU "KhPI", 2016.

13. Shvets N.V., Shevtsova H.Z. Improvement of methodological approaches to the estimation of the competitiveness of industry // Ekonomichnyi visnyk DonbasuEconomic Bulletin of Donbas. - 2018. - No. 2 (52). - P.114123.

14. Shevtsova H.Z., Maslosh O.V. The Ukrainian chemical industry. In the searches of new strategy of development // Hlobalni ta natsionalni problemy ekonomiky - Global and National Problems of Economic. - 2017. - No. 16. - P.249253.

15. Chernysheva O.M. Modelling of management decisions for enterprises strategy formation. - Topical questions of contemporary science: Collection of scientific articles, 2017. P.188-191.

16. Chernysheva O.M. Tire enterprises strategy: applied aspects. Ekonomichnyi visnyk DVNZ UDKhTU - Economic Bulletin of SHEI "Ukrainian State University of Chemical Technology”. - 2016. - No. 2 (4). - P.146-152.

Received 07.04.2019

Reviewer: Doct. of Econ. Sc., Prof. Dubnitskyi V.I.

\section{НАУКОВО-МЕТОДИЧНЕ ЗАБЕЗПЕЧЕННЯ ПРОЦЕСУ ФОРМУВАННЯ СТРАТЕГІЇ ПІДПРИЕМСТВ ХІМІЧНОЇ ПРОМИСЛОВОСТІ}

\section{Паршина О.А., Чернишева О.М., Яшкіна Н.В.}

Статтю присвячено обгрунтуванню складових науково-методичного забезпечення процесу формування стратегії підприємств хімічної промисловості. Зазначено, що інтеграційні процеси вітчизняних підприємств хімічної промисловості зумовлюють необхідність розробки нових підходів до формування стратегії в умовах підвищення конкурениії на внутрішньому та зовнішньому ринках. За допомогою аналізу наукових робіт доведено доцільність застосування індивідуального підходу для обтрунтування науково-методичних рекомендацій щодо змісту етапів формування стратегії підприємств окремого сектора галузі на основі підвищення рівня конкурентоспроможності продукції. Зазначено, що метою діяльності підприємств хімічної промисловості доиільно вважсати забезпечення сталого розвитку. Побудовано систему формування стратегії підприємств шинного виробництва, у якій керуюча підсистема заснована на елементах економічного механізму, а процес - на етапах регулювання рівня конкурентоспроможності типорозміру шин. Запропоновано науково-методичне забезпечення процесу формування стратегії підприємств шинного виробництва, яке передбачає комплекс економічних методів, способів, важелів та інструментів для кожного з етапів регулювання рівня конкуренто- спроможності окремого типорозміру шин у стратегічних зонах господарювання та визначення географічного вектора зростання, конкурентних переваг, синергізму та стратегічної гнучкості портфеля стратегічних зон господарювання для сприяння сталому розвитку підприємства. Специфічними показниками запропонованого науково-методичного забезпечення є інтегральний показник оцінювання та потенційно можливий рівень конкурентоспроможності моделі шин окремого типорозміру, резерв конкурентоспроможності продукції підприємства. У якості нормативів інтегрального показника конкурентоспроможності моделі шин окремого типорозміру для нової або модернізованої продукції запропоновано мінімальний рівень конкурентоспроможності, який забезпечує споживчу привабливість даної продукції, та мінімальний рівень результативності управління конкурентоспроможністю продукції підприємства.

Ключові слова: стратегія підприємства, процес формування стратегії, конкурентоспроможність продукції, хімічна промисловість, шинне виробництво.

\section{НАУЧНО-МЕТОДИЧЕСКОЕ ОБЕСПЕЧЕНИЕ ПРОЦЕССА ФОРМИРОВАНИЯ СТРАТЕГИИ ПРЕДПРИЯТИЙ ХИМИЧЕСКОЙ ПРОМЫШЛЕННОСТИ}

\section{Паршина Е.А., Чернышева Е.М., Яикина Н.В.}

Статья посвящена обоснованию составляющих научнометодического обеспечения процесса формирования стратегии предприятий химической промышленности. Отмечено, что интеграционные процессы отечественных предприятий химической промышленности обусловливают необходимость разработки новых подходов к формированию стратегии в условиях усиления конкуренции на внутреннем и внешнем рынках. С помощью анализа научных работ доказана целесообразность применения индивидуального подхода для обоснования научно-методических рекомендаций по содержанию этапов формирования стратегии предприятий отдельного сектора отрасли на основе повышения уровня конкурентоспособности продукции. Отмечено, что целью деятельности предприятий химической промышленности целесообразно считать обеспечения устойчивого развития. Построена система формирования стратегии предприятий шинного производства, в которой управляющая система основана на элементах экономического механизма, а процесс - на этапах регулирования уровня конкурентоспособности типоразмера шин. Предложено научно-методическое обеспечение процесса формирования стратегии предприятий шинного производства, которое предусматривает комплекс экономических методов, способов, рычагов и инструментов для каждого из этапов регулирования уровня конкурентоспособности отдельного типоразмера шин в стратегических зонах хозяйствования и определение географического вектора роста, конкурентных преимуществ, синергизма и стратегической гибкости портфеля стратегических зон хозяйствования для содействия устойчивого развития предприятия. Сneцифическими показателями предложенного научно-методического обеспечения являются интегральный показатель оиенки и потенциально возможный уровень конкурентоспособности модели шин отдельного типоразмера, резерв конкурентоспособности продукции предприятия. В качестве нормативов интегрального показателя конкурентоспособности модели шин отдельного типоразмера для новой или модернизированной продукции предложен минимальный уровень конкурентоспособности модели шин отдельного типоразмера для новой или модернизированной продукции предложсено минимальный уровень результативности управления конкурентоспособностью продукции предприятия.

Ключевые слова: стратегия предприятия, процесс формирования стратегии, конкурентоспособность продукции, химическая промышленность, шинное производство. 


\section{SCIENTIFIC AND METHODOLOGICAL PROVIDING OF THE FORMING PROCESS OF THE CHEMICAL INDUSTRY ENTERPRISES STRATEGY}

\author{
Parshyna O.A. ${ }^{a}$, Chernysheva O.M. ${ }^{b, *}$, Yashkina N.V. ${ }^{b}$ \\ a Dniepropetrovsk State University of Internal Affairs, Dnipro, \\ Ukraine \\ ' SHEI «Ukrainian State University of Chemical Technology»,
Dnipro, Ukraine
}

\section{* e-mail: chernysheva197411@gmail.com}

The article is dedicated to the reasoning of the components of scientific and methodological providing the process of the chemical industry enterprises strategy formation. It has been noted that the integration processes of domestic enterprises of the chemical industry predetermine the necessity of the elaboration of new approaches to the strategy formation in conditions of the increasing of competition on the domestic and foreign markets. Through analysis of scientific papers the feasibility of individual approach to substantiating the methodological recommendations for the content of stages of the enterprise strategy formation for a single industry sector has been proved. These stages are based on the improving the competitiveness of products. It has been noted that the providing of sustainable development should become the object of activity of the chemical industry enterprises. The system of the formation of the tire enterprises strategy has been constructed. The management subsystem within it is based on the elements of the economic mechanism meanwhile the process - on the stages of the regulation of the level of competitiveness of tires standard size. The scientific and methodological providing the process of the tire enterprises strategy formation has been offered. This providing covers a set of economic methods, means, levers and tools for every stage of regulation of the level of competitiveness of separate standard size of tires in the strategic management zones as well as a determination of the geographic vector of growth, competitive advantages, synergism and strategic flexibility of the strategic management zones portfolio for the assistance to enterprise sustainable development. The specific indexes of this providing are: integral index of estimation and potentially possible level of competitiveness of a model of separate standard size of tires as well as the reserve of the enterprise product competitiveness. Minimum level of competitiveness for the providing the consumer attractiveness of the product and minimum level of management outcome of competitiveness of the enterprise product have been offered as standards of integral index of competitiveness of a model of separate standard size of tires.

Keywords: enterprise strategy, process of strategy formation, product competitiveness, chemical industry, tire production.

\section{REFERENCES}

1. Kovenia T.V. (2017). Systemna analitychna otsinka osnovnykh zmin, yaki vidbulysia v khimichnii promyslovosti Ukrainy v 2017 rotsi ta v poperedni roky [System assessment of the main changes in the Ukrainian chemical industry in 2017 and previous years]. Khimichna promyslovist Ukrainy - Chemical Industry of Ukraine, 3, 19-46 [in Ukrainian].

2. Krasnokutska N.S. (2012). Kontseptsiia tsinnisno-oriientovanoho upravlinnia potentsialom pidpryiemstva [Concept of value-oriented management of the enterprise potential]. Aktualni problemy ekonomiky - Actual Problems of Economic, 8, 23-29 [in Ukrainian].

3. Oleshko V.V. (2015). Misiia ta tsili stratehii staloho rozvytku pidpryiemstv khimichnoi haluzi [Mission and goals of the sustainable development of the chemical industry enterprises]. Ahrosvit - Agro World, 9, 60-64 [in Ukrainian].

4. Pavlenko I.I. (2016). Metodychni pidkhody do otsinky konkurentospromozhnosti produktsii pidpryiemstv khimichnoi promyslovosti [Methodological approaches to the estimation of competitivness of the chemical industry enterprises]. Derzhava ta rehiony - State and Regions, 1(88), 65-68 [in Ukrainian].

5. Pavlenko I.I. (2015). Otsinka potentsialu pidvyschennia konkorentospromozhnosti pidpryiemstv khimichnoi promyslovosti [Estimation of the potential of increasing of the competitiveness of the chemical industry enterprises]. Teoretychni ta praktychni aspekty ekonomiky intelektualnoi vlasnosti - Theoretical and Practical Aspects of the Economy of Intellectual Property, 2(12), Vol. 3, 8-13 [in Ukrainian].

6. Pavlenko I.I. (2016). Formuvannia konkurentnykh perevah u shynnomu vyrobnytstvi [Formation of the competitive advantages in the tire production]. Ekonomichnyi prostir - Economic Space, 106, 200-208 [in Ukrainian].

7. Pererva P.H. (2013). Formuvannia stratehii rozvytku pidpryiemstv khimichnoi promyslovosti [Formation of the strategy of development of the chemical industry enterprises]. Visnyk NTU "KhPI" - Bulletin of NTU "KhPI", 21, 112-119. Retrieved from http://nbuv.gov.ua/UJRN/vcpitp_2013_21_19 [in Ukrainian].

8. Fedorenko I.A. (2013). Razvitiie teploenerheticheskikh rynkov rehionov v usloviiakh konkurentnoi sredy [Development of heat and energy regional markets in the conditions of competitive environment]. Investytsii: praktyka ta dosvid - Investments: Practice and Experience, 11, 8-10 [in Russian].

9. Khadzhinova Ye.V. (2015). Intehratsionnyie obyedineniia kak faktor povysheniia konkurentosposobnosti predpriyatii khimicheskoi otrasli [Integration associations as a factor to increase the competitiveness of enterprises of the chemical industry]. Teoretychni ta praktychni aspekty ekonomiky intelektualnoi vlasnosti - Theoretical and Practical Aspects of the Economy of Intellectual Property, 2(12), Vol. 2, 185-193 [in Russian].

10. Khadzhinova Ye.V. (2016). Systemnyi pidkhid do pidvyshchennia konkurentospromozhnosti pidpryiemstv shynnoho vyrobnytstva [System approach to the increasing of the competitiveness of enterprises of the tire production]. Ekonomichnyi prostir - Economic Space, 108, 236-245 [in Ukrainian].

11. Chernysheva O.M. (2011). Metodyka upravlinnia konkurentospromozhnistiu dyversyfikovanoho pidpryiemstva [Methodology of management of the competitiveness of the diversified enterprise]. Proceeding of Chemistry and Modern Technologies: V Mizhnarodna naukovo-telhnichna konferentsia "Khimia ta suchasni tekhnolohii" - The Fifth International Scientific and Technical Conference "Chemistry and Modern Technologies". (Vols. 2), (P. 79). Dnipropetrovsk: DVNZ UDKhTU [in Ukrainian].

12. Chernysheva O.M. (2016). Otsinka konkurentospromozhnosti produktsii pidpruiemst shynnoho vyrobnytstva [Estimation of the tire enterprises production competitiveness]. Extended abstract of candidate's thesis. Kharkiv: NTU "KhPI" [in Ukrainian].

13. Shvets N.V., \& Shevtsova H.Z. (2018). Udoskonalennia metodychnykh pidkhodiv do otsiniuvannia konkurentospromozhnosti haluzi [Improvement of methodological approaches to the estimation of the competitiveness of industry]. Ekonomichnyi visnyk Donbasu - Economic Bulletin of Donbas, 2 (52), 114-123 [in Ukrainian].

14. Shevtsova H.Z. \& Maslosh O.V. (2017). Khimichna promyslovist Ukrainy. U poshukakh novoi stratehii rozvytku [The Ukrainian chemical industry. In the searches of new strategy of development]. Hlobalni ta natsionalni problemy ekonomiky - Global and National Problems of Economic, 16, 249-253 [in Ukrainian].

15. Chernysheva O.M. (2017). Modelling of management decisions for enterprises strategy formation. Topical questions of contemporary science: Collection of scientific articles. (pp. 188191). Taunton, MA, United States of America: Aspekt Publishing [in English].

16. Chernysheva O.M. (2016). Tire enterprises strategy: applied aspects. Ekonomichnyi visnyk DVNZ UDKhTU - Economic Bulletin of SHEI "Ukrainian State University of Chemical Technology", 2 (4), 146-152 [in English]. 